\title{
Fish Biodiversity: Brief Perspective to the use of the Environmental DNA in Brazilian Amazon
}

\section{Santos CHA*}

Brazilian National Research Institute of the Amazon (INPA), Brazil

*Corresponding author: Carlos Henrique dos Anjos dos Santos, Brazilian National Research Institute of the Amazon (INPA), Laboratory of Ecophysiology and Molecular Evolution (LEEM), 69067375, Manaus, AM, Brazil, Tel: +55 (92) 3643-3190; Email: carloshenrique@inpa.gov.br

Review Article

Volume 4 Issue 2

Received Date: February 09, 2020

Published Date: March 24, 2020

DOI: $10.23880 /$ jenr- 16000191

\section{Abstract}

The Amazon basin is an important region and intriguing in terms of freshwater fish diversity. Traditional methods have been essential in knowledge the species diversity, but new methods are fundamental to the biodiversity monitoring. The environmental DNA is a novel, sensitive, efficient, and effective and no invasive method in biological research, but their sensitivity has not yet been fully evaluated, and the probability of detecting species at the site of study has been shown to be dependent of a genetic database, species distribution, and of environmental factors. Thus, some factors need to be clarified to a routine application of eDNA method in the Amazon basin, and that their results can contribute in public and environmental policies in the region.

Keywords: Amazon Basin; Conservation; Fish Diversity; Environmental Policy

\section{Why Preserve the Amazonian Ich thyofauna?}

Global environmental transformations and the preservation Amazonian tropical forest and their biodiversity (see Glossary) has become a central theme in the debates about climate and environmental change across the world $[1,2]$. But not only forests, more also water resources are of great ecological and environmental importance to region (e.g., a quarter of the world's freshwater is in the Brazilian Amazon), as well as its ichthyological richness that is food base to the Amazonian peoples. To the worldwide population ( $>7$ billion people) the fish is an important and essential element in the economy and have been the main feed of many people [3]. Junk et al. [4] have report that despite the clear dependency of the human population by the fisheries resources, governments have failed to develop strategies and methods for sustainable management of their aquatic ecosystems, and their protection therefore generally not is considered in the planning of large development projects, which inevitably pose serious risks to the integrity of aquatic ecosystems and the maintenance of aquatic biodiversity (e.g., Belo Monte Hydroelectric Power Plant in the Rio Xingu, Pará, Brazil).

Surprisingly the ichthyofauna marine and freshwater of South America is a of the most diverse on Earth, and with estimates above 9,100 species, that is about $27.0 \%$ of all fishes worldwide $(35,000$ fish species described) $[5,6]$. According to Tedesco et al. [7], there are about 14,953 fish species inhabiting permanently or occasionally the freshwater systems to the world, and that is a disproportionately highly fraction of the global fish diversity considering the small proportion of the earth's surface that they occupy. In the Brazilian territory, only the Amazon hydrographic basin has an area of drainage with 5.8 millions $\mathrm{km}^{2}$ [8], and their water are rich in number of fish species (Box 1 ), with more than 3,000 known species (2,072 would be species endemic) and distributed by basal goups up to the more specialized ones $[9,10]$. However, this high diversity of species still can be bigger, when mentioned the new species that are being discovered and described, increasing the endemic species number in the region. 


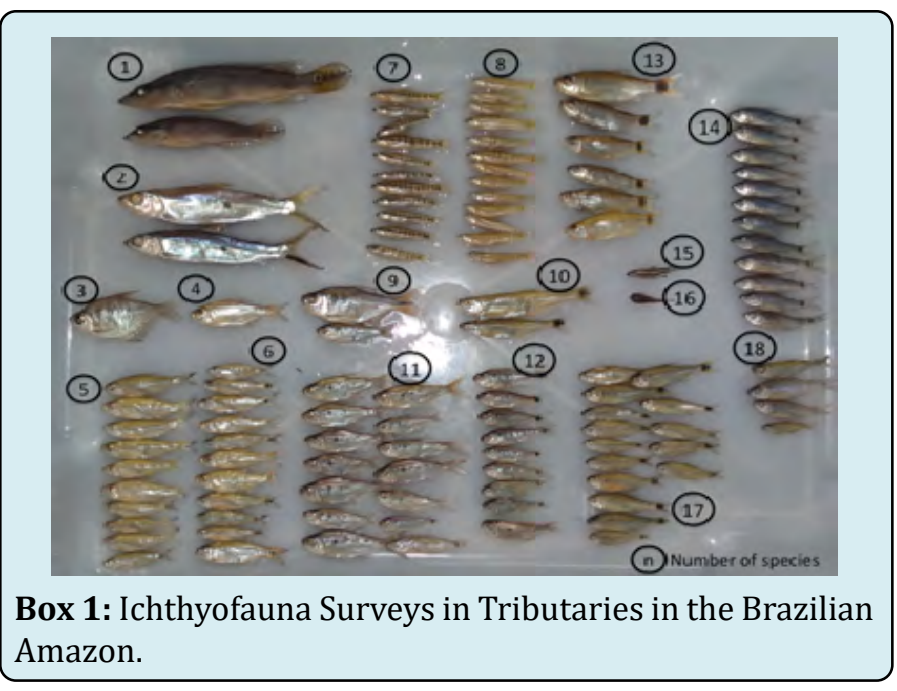

Among vertebrates, fish are one of the most diverse groups, and the freshwater fish occur only in less than $0.003 \%$ (by volume) of the world's aquatic ecosystems [11]. The number of fish species in Brazilian continental aquatic ecosystems is still inaccurate and difficult to estimate, but by far the Amazonian aquatic ecosystems are the most diverse (Figure I). The Brazil is considered a leader in freshwater fish numbers, and only in the Brazilian Amazon are estimated $+3,000$ species with high rates of endemism $[9,10]$. Estimates indicate that 30 to $40 \%$ of neotropical freshwater continental fish fauna have not yet been described $[5,9,12]$, and these estimates are reinforced when we take into account that approximately 400 new species of fish have been described in the last decade in continental waters [11]. For Piorski et al. [13], it is highly important to understand how neotropical freshwater fish biodiversity, in specially Amazonian, is generated and maintained, as habitats are being transformed by human development and fish communities have been intensively exploited as a sustaining food for population growth. Thus, the use of new methods for the monitoring of the Amazonian ichthyofauna is necessary, and the classical and new methods (e.g., environmental DNA; see Figure 1) will be essential for a more accurate and efficient estimation, with the aquactic environment changes caused by man.

The eDNA is a non-invasive method and is available as an monitoring tool for wildlife.

Mid-1992, the Conference of the United Nations on Environment and Development was realized in Rio de Janeiro, Brazil, to discuss the sustainable of the global biodiversity ant its conservation for future generations, and in this meeting the participating countries signed to Convention on Biological Diversity (CBD) [14]. Unfortunately, the signing of the CBD not is a guarantee that participatin countries will create clear public policies, and that would bar the risks of lost of the global biodiversity. However, what happens is that countries that do not have a public policy aimed at maintaining and conserving their biodiversity, have registered an increase in the number of extinction threatened species. In this context, it as become essential and necessary to apply new methods that are efficient in the monitoring local biodiversity, and that can assist in the public policies aimed at the conservation of priority areas, as well as protect our extinction threatened species.

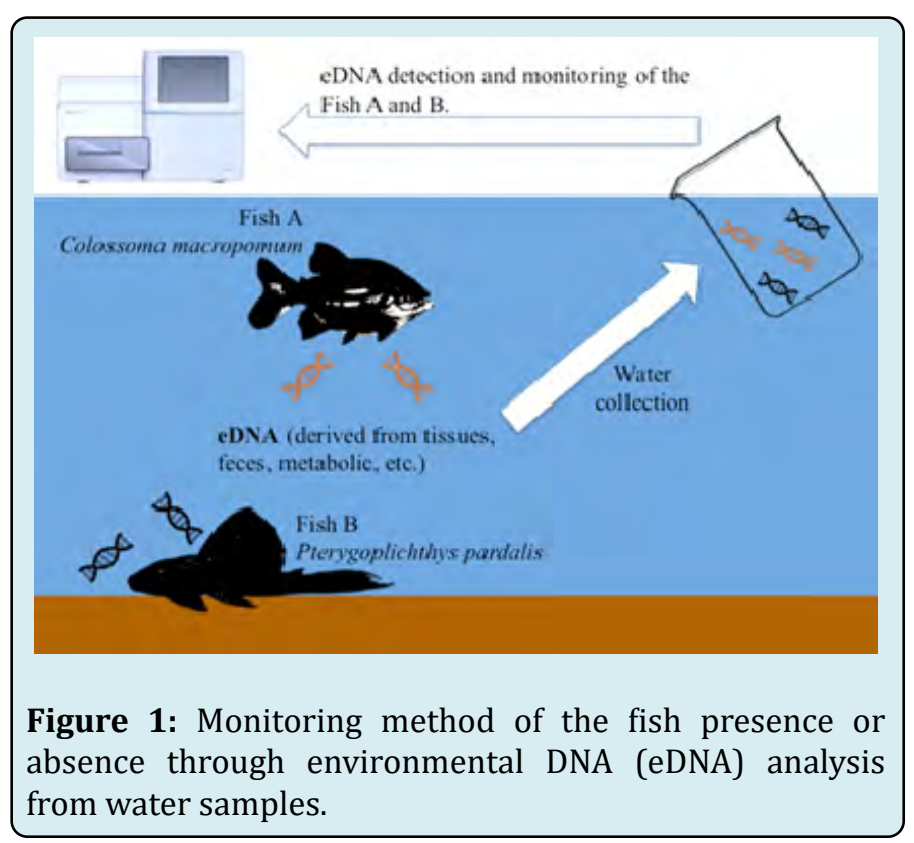

Here we approache subjectively the challenges on the use environmental DNA in the monitoring of fishe species in the Brazilian Amazon, and how it can improve monitoring programs and bring feedback for the public policies. Our primary aim is to show the challenges in the application of eDNA on the survey and monitoring Amazonian aquatic biodiversity, and as its use can collaborate in decisionmaking in the environmental policies for the management and conservation of our fishery resources.

\section{Distribution Patterns and the Conventional Methods for Estimated the Fish Biodiversity}

Some studies have shown that the distribution of fish species in rivers has following ecological traits in associated with the preference of the environmental conditions requerid to the species, and this has been well documented in literature. This shows that changes to the availability of preferred habitat units (as waterfalls, streams, lakes, lagoos, and igarapés) has contributed to shifts in the functional composition of fish communities and in the diversity due to species-specific and trait-environment interactions [15]. Other studies also approached on the importance of climate in regulating population sizes across a species geographical range in aquatic taxa [16], and as the warming of waters 
can influenced in the distribution of organisms that live in freshwater environment [17]. In the Amazonian region, we highlight also flood pulses (Box 2) influence on the fish distribution in rivers, due main to the annual cycles of flood and ebb in the floodplains areas.

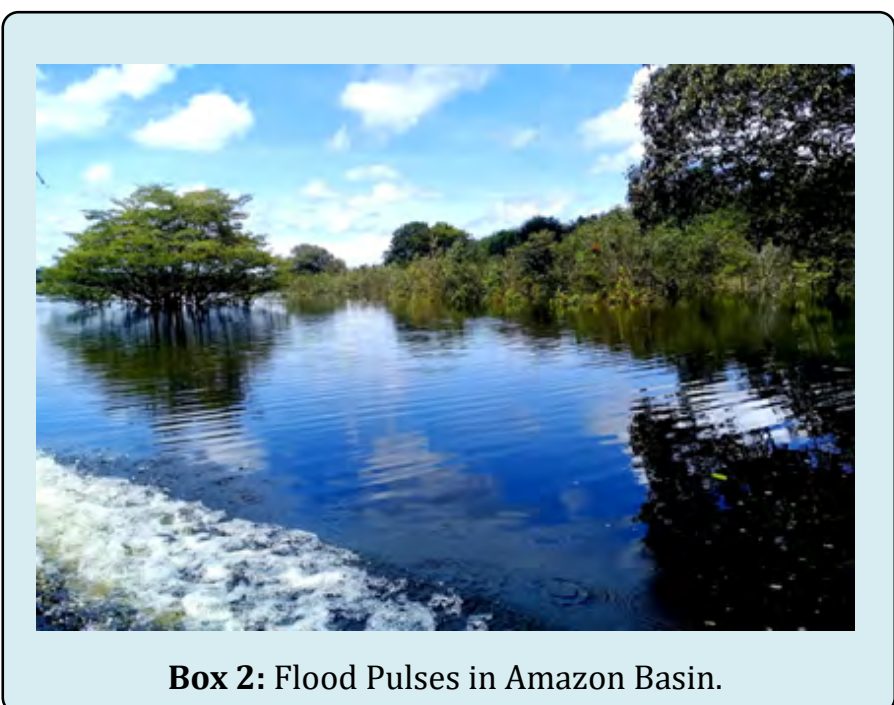

(Figure 1) Flood period in a Rio Negro tributary (Photograph: Larissa Matos). In floodplains areas, only the tops of the tallest trees are not submerged with rising waters during the flood pulses. The lower areas form a huge flood area that can stay submerged for up to 6 months before the waters return to the main river, and form important feeding and breeding areas to fish species.

Amazon basin seasonally fluctuating water levels are known as 'flood pulses', and promote high rates of biological production and drive the fish biodiversity in Amazon. There over, the flood pulses influence in the rising (Figure 1) and declining water levels, as well as in the dynamics of fish populations in the Amazonian rivers that migrated laterally out of river channels to the areas flooded floodplains $[18,19]$. The effects climate changes in the Amazon region also can cause changes in precipitation and regional hydrological regime, affected the flood pulses and the fishes species reproductive success [20]. However, the areas seasonally flood plain formed by white water rivers are known of várzeas, and the formed by black water rivers are known of igapós, and these environment seasonally change in direction, changing also the local landscape and the distribution of fish species. To Alsdorf et al. [21], the temporal changes in flood water heights are more complex than typically assumed, and affected also the flow of some rivers. It's clear that flood pulses are responsible for the distribution of fish species in Amazonian water bodies, and this will also have a direct impact on environmental DNA "eDNA" studies (changes in eDNA concentrations).
In general, the ecological processes are directly related to the spatial and temporal patterns in the species distribution, and thus some conservation plans has require more accurate estimates on spatial distribution of the species that if intended to protect [22]. On the other hand, the temporal patterns shown to be more interesting to the future trends in the species distribution and of the local biodiversity when compared to the spatial patterns $[23,24]$. Thus, accurate results on the spatial and temporal distribution of fish communities, we will need to carefully evaluate the methods used for these purposes, as well as verified the effects of the biotic and abiotic factors on the distribution of the species. Therefore, only with robust and reliable results in the monitoring of local biodiversity, will to be possible use the data to the making decision and implement public policies aimed at the conservation and preservation of local biodiversity.

To this, a variety of sampling methods are used for monitoring and estimative the fish biodiversity (e.g., seine nets, boat electro fishers, hoop nets, Windermere traps, trap nets, and minnow traps; see Lapointe and Corkum [25]), and studies have showed that only some fish taxa are selected to one habitat type and sampling method [26], generating gaps in the surveys data. On the other hand, the traditional methods have significantly contributed to the knowledge of the ichthyofauna of the Brasilian Amazonian, but these methods are selective in relation to the species, and therefore do not cover the real diversity [27]. In tropical freshwater ecosystems the fishes assemblages contain dozens of species, and their observation ends up being limited by water turbidity, depth and rivers water velocity [28]. Thus, the applied of new method has been essential to biodiversity monitoring, and the environmental DNA (eDNA) method has shown promise in the monitoring and estimative aquatic biodiversity, and their results show to be similar to the found with the traditional fisheries capture methods [29]. However, in order to be able to accurately compare the eDNA method with the classical collection methods, a local genetic database (target-gene or mitogenome) for verified the species that occur in the studied areas is necessary, and their temporal and spatial distributions.

\section{The Use of the Environmental DNA in the Fish Biodiversity Monitoring}

The biodiversity monitoring and assessment are essential to ensure a healthy aquatic environment, mainly with the increasing human activity and the use of their natural resources in the Brazilian amazonian. However, the use traditional biodiversity methods is costly and they often employ traditional morphology-based taxonomy, which requires a taxonomic expert to manually identify individual organisms captured in the studied areas [30]. However, 


\section{Journal of Ecology and Natural Resources}

these methods have left gaps in the actual estimate of local biodiversity, be they for the temporal or spatial distribution data.

The environmental DNA (eDNA) it's been a novel, sensitive, efficient, effective and noninvasive method in the biological biodiversity monitoring [31], and have enabled up a whole range of taxonomic groups across large geographical regions for study [32]. The technique is based on the capture of eDNA in environmental samples (water, soil, air, and ice cores) and genetic analysis of metabarcoding eDNA (Figure 1) and quantitative PCR (qPCR) data [33,34]. Some studies have attributes particularities to eDNA analyses making this technique an important tool also to elucidate the evolutionary and ecological processes in fish communities [35]. Nonetheless, their application is still considered as recent in the monitoring and distribution of indigenous and non-indigenous species [36,37]. On the other hand, the sensitivity of the eDNA method has not yet been fully evaluated, and the probability of detecting the targetDNA at the site of study has been shown to be dependent on the concentration and dispersion of eDNA molecules [38], persistence of eDNA in the aquatic environment [39], preservation of the filters until the time of analysis [40], and the several methods of eDNA extracting [41].

Faced with this, becomes evident the need for the standardization of eDNA method for new areas is evident, and in the case of the Amazon Basin, some factors will have to be overcome, as: (1) the water types and their peculiarities (black, clear, and white waters; see Junk et al. [4]); (2) their hydrographic basin of continental size; (3) the high fish species diversity (known and unknown), (4) the influence of flood pulses on ichthyofauna distribution, and (5) the presence of areas still untouched to man. The high fish species diversity can been considered a factor negative when comparing with other aquatic ecosystems of the world, mainly by the ausence of robust genetic database for the our species, which would make it difficult to apply the eDNA method more efficiently. According to Ravindran [32], at the moment only about $15 \%$ of the Amazonian fish species that we find can be given a name (species that have some genetic information in international databases, e.g., NCBI, MitoFish, and BOLD). Moreover, many areas in the Brazilian Amazon still are untouched by the man, which would increase the possibility of finding new species of fish not yet were cataloged by science, and that probably already are endangered species due the climate change and high endesmism rate in the region.

Therefore, studies have shows that the eDNA technique is highly sensitive to detection of species in stationary waters is becoming increasingly clear its application, in the opposite way studies in running water are still necessary due to the controversial results obtained $[42,43]$. Even so, the application of eDNA are especially promising in rivers, where eDNA can integrate information efficient about populations upstream [44], but we have to emphasize that the rivers of the Brazilian Amazonian are oceans true when compared to other rivers, mainly in the flood periods (Box 2). An important study accomplished by Cilleros et al. [28], has shown that the fish assemblage compositions in different drainage basins in the French Guiana (area of the Amazon basin) was better discriminated with the use metabarcoding eDNA, revealing that while traditional methods provide a more complete, however spatially limited inventory, metabarcoding provides a more partial and but spatially extensive inventory. On the other hand, some studies show that the comparison to conventional ecological techniques and the eDNA in the estimating population sizes, still doesn't necessarily reflect its abundance in the environment, making it difficult to translate a PCR result into population estimates real [32]. To Carraro et al. [45], we still currently lack a method to extract quantitative information about the location and density of populations contributes with the eDNA signal.

Thus, great efforts will be necessary for the eDNA method to be routinely applied in areas of the Amazon basin, and for its results to contribute to the environmental policies in the region. Following this path, several research centres in the Brazilian Amazon started to apply the eDNA method, but as previously mentioned, some challenges have to be overcome so that the results obtained can be used future in public policy, being the main challenge the construction of a local genetic database.

\section{Genetic Database for the Amazon Basin Fish}

Global databases on fishes lack fish diversity information at regional scale of a country, and the databases are today essential part of the biodiversity science and have been used widely in locan and region biological research [46]. Despite the high diversity of fish species in the Brazilian Amazon, only some species have any genetic information contained in international databases. But it is noteworthy that the most information present in these databases are partials and therefore incomplete. Overall, are few Amazonian fish species that have their complete nuclear and mitochondrial genomes.

On the otherhand,theDNAhigh-throughputsequencing based strategies require good reference databases, and the taxonomic specialists are still required to build the reference databases against which eDNA is matched be to identify species [32]. Thus, the field collection to capture specimens for knowledge of local biodiversity with the use traditional capture methods, ichthyology collections and museums are still crucial sources for obtaining biological materials for 


\section{Journal of Ecology and Natural Resources}

the genome or mitogenome sequecing of the ichthyofauna of the Amazon basin. When complete mitochondrial genome sequencing is not possible, we recommend partial or complete sequencing of taxonomic marker genes (e.g., Cytochrome c oxidase subunit I (COI), cytochrome b (Cyt-b), $12 \mathrm{~S}$ ribosomal RNA (12S rRNA), and 16S ribosomal RNA (16S rRNA)).

Given this, the creation of platform for sharing fish genomic and mitochondrial sequences has facilitated the access of high-performance computational resources for genome and mitogenome data analyses. Today, the main genetic databases are available in the World Wide Web domain (see FisOmics [47]; MitoFish [48,49]; FishTrace [50]; Fish Mitogenome Resource (FMiR) [51]; Barcode of Life Database System (BOLD) [52]; and National Centre for Biotechnology Information (NCBI) RefSeq database [53]). However, it will also be very important to create local platforms for eDNA work, especially in areas that are highly diverse in number of species, as is the case of the Amazon basin.

\section{Challenges and the use eDNA in decision- making}

The use of new methods for monitoring global biodiversity has made eDNA a promising method for biodiversity studies, but their use in environmental policies is not yet certain. Nowadays, there is an urgent need to develop new tool biological assessment tools that can provide baseline information and rapidly identify change in the local biodiversity and that can been applied in environmental policies [54]. And in this context, the eDNA method shown to be an important tool and with enormous potential for use in environmental policy of conservation and protection of local biodiversity.

On the other hand, we need to recognize that a regulated framework for the validation of eDNA-based methods needs to be established to enable decision-makers to have confidence in applying these method. Despite its recent development, the eDNA method will continue to influence careers and policies for years to come, and it will be paramount to ensure collaboration is maintained between investigation bodies and public policy sectors the to put effort into conveying the importance of such findings to the public and the managers to decision-making [55]. The eDNA method brings together several fields for the assessment of communities for purposes ranging from ecosystem restoration to human health, making it extremely versatile and vital to the future of molecular research and public policies [54].

In general, all decisions are based on the decision maker's values, and the science can and should help decision makers by shaping their values and beliefs to make better decisions [56]. The author still points out that unfortunately, science is not easily accessible to decision makers, and scientists often do not understand decision makers' information needs. Therefore, it is important that both scientists and managers are willing to be actors in the complex process of proposing and applying public policies that are beneficial to society and the environment (Figure 2). Nowadays, the greatest example of complexity between science and decision makers (managers) are the climate change (scientific knowledge) and the proposals to minimize its effects on land (public or environmental policies).

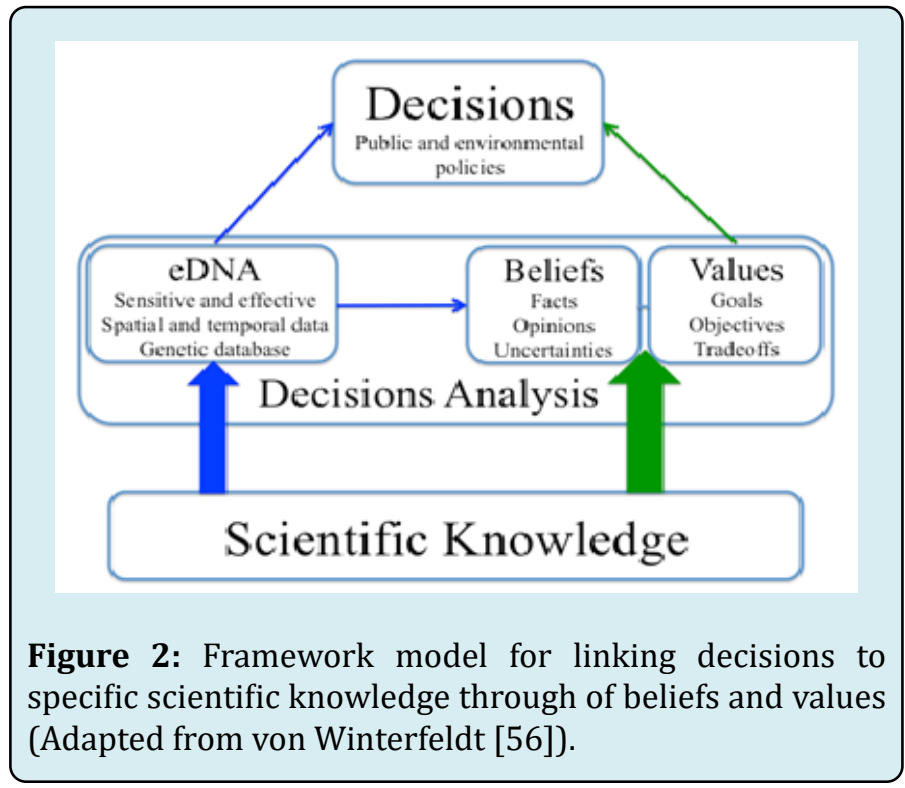

The present model can be exercised without any reference to science at all, merely by using a decision maker's beliefs and values, whether they are informed by science or not. To von Winterfelt (2013), the bayesian statisticians and analysts take it for granted that beliefs are up-dated by information and that expert opinions matter when revising beliefs. Therefore, specific scientific knowledge - through established scientific facts or expert opinion (eDNA, blue arrow) - can and should influence the beliefs and values of decision makers (green arrow).

\section{Concluding Remarks}

In general, for an accurate application of eDNA in Amazonian aquatic environments, it is necessary to fill in some gaps about the method that need to be better studied before being applied routinely in the region. One of the larger challenges will be to expand the genetic database with information's of genomes mitochondria is or the complete sequencing of mitochondrial target-genes (12S, $16 \mathrm{~S}$, COI and Cytb) of the fishes species of the Amazon 


\section{Journal of Ecology and Natural Resources}

basin. However, the traditional fisheries capture methods, museums, and ichthyologic collections of the Amazonian region will be essential to achieve the goal of construct a local genetic database to the eDNA studies. Another point will be to establish a standardization of the eDNA method for the activities laboratorial and field, the that can contribute to efficiency and improvement of the technique for the aquatic environments of the Amazon basin. There over, it will be necessary for the information generated by the eDNA method to be transmitted to decision makers and that they to make decisions that strengthen environmental policies in the Amazon region. To this, we have to make scientific knowledge accessible to decision makers, and scientists will play a key role in translating the information generated so that managers can make the right decisions with the reality of the moment.

\section{Glossary}

Biodiversity: is defined by the Convention on Biological Diversity (CBD) as the variability of living organisms from all sources, including but not limited to terrestrial, marine and other aquatic ecosystems and the ecological complexes that are part of them; further comprising diversity within species, between species and ecosystems.

Endemic species: these are species that occur naturally in a specific region, that is, are exclusive species and do not occur outside of your specific regions.

Environmental DNA (eDNA): is the sum of all DNA molecules isolated from water, sediments or any other substrate.

Fish communities: fish species composition or diversity that are influenced by the distribution patterns and that reflect the availability of the resources and their biological interactions between species, meeting social and economic needed.

Flood pulses: it is the hydrological characteristics of the river (biologic and biogeochemical processes), its drainage basin and its floodplain, which periodically receive a input or lateral exchange of the river waters and its floodplains as well as the exchanges between the terrestrial phases (ebb/dry) and aquatic (flood/crowded), being of particular interest in the Amazon region those associated with rivers and lakes.

Genetic database: they are platforms where nuclear and mitochondrial DNA sequences from sequenced prokaryotes and eukaryotes (species level) samples are stored and made available for search by anyone.

High-throughput sequencing: the simultaneous sequencing of millions of DNA fragments.

Hydrographic basin: set of lands where water is collected for a main river and its tributaries; in a watershed, water flows from springs to lower points, forming waterfalls, streams and lakes that create a main river.

Indigenous species: occurs naturally in a given ecosystem or region, that is, lives and grows within its natural limits including its potential areas of dispersal.

Metabarcoding eDNA: high-throughput sequencing of PCRamplified taxonomic marker genes that characterizes eDNA of multiple species from a single sample.

Non-indigenous species: when a species does not inhabit its natural local, that is, when it was introduced by man in a certain local, then this species is considered an exotic species for that local.

Taxonomic marker genes: genes regularly used in taxonomic identification [e.g., cytochrome c oxidase subunit I (COI), cytochrome b (Cyt-b), ribosomal RNA (12S rRNA and 16S rRNA)].

\section{Acknowledgment}

We acknowledge the Brazilian National Council for Scientific and Technological Development (CNPq) by the PCI/INPA fellowship (CNPq \#301402/2019-1) granted to CHAS to conduct research activities in the Brazilian National Research Institute of the Amazon (INPA)

\section{References}

1. Heckenberger MJ, Russell JC, Toney JR, Schmidt MJ (2007) The legacy of cultural landscapes in the Brazilian Amazon: implications for biodiversity. Phil Trans R Soc B 362(1478): 197-208.

2. Castello L, McGrath DG, Hess LL, Coe MT, Lefebvre PA, et al. (2013) The vulnerability of Amazon freshwater ecosystems. Conserv Lett 6(4): 217-222.

3. Guo Q, Liu X, Ao X, Qin J, Wu X, et al. (2018) Fish diversity in the middle and lower reaches of the Ganjiang River of China: Threats and conservation. PLOS ONE 13: e0205116.

4. Junk WJ, Maria Gercilia MS, Bayley PB (2007) Freshwater fishes of the Amazon River basin: their biodiversity, fisheries, and habitats. Aquat Ecosyst Health Manag 10(2): 153-173.

5. Reis RE, Albert JS, Dario FD, Mincarone MM, Petry P, et al. (2016) Fish biodiversity and conservation in South America. J Fish Biol 89(1): 12-47.

6. Mariac C, Vigouroux Y, Duponchelle F, García-Dávila C, Nunez J, et al. (2018) Metabarcoding by capture using a single COI probe (MCSP) to identify and quantify fish species in ichthyoplankton swarms. PLoS ONE 13: e0202976.

7. Tedesco PA, Beauchard O, Bigorne R, Blanchet S, Buisson L, et al. (2017) Data Descriptor: A global database on freshwater fish species occurrence in drainage basins. 


\section{Journal of Ecology and Natural Resources}

Sci Data 4: 170141.

8. Ardura A, Rosa Linde A, Moreira JC, Garcia-Vazqueza E (2010) DNA barcoding for conservation and management of Amazonian commercial fish. Biol Conserv 143(6): 1438-1443.

9. Lévêque C, Oberdorff T, Paugy D, Stiassny MLJ, Tedesco PA (2008) Global diversity of fish (Pisces) in freshwater. Hidrobiologia 595: 545-567.

10. Val AL (2019) Fishes of the Amazon: diversity and beyond. An Acad Bras Cienc 91(S3): e20190260.

11. Agostinho AA (2005) Conservação da biodiversidade em águas continentais do Brasil. Megadiversidade 1(1): 7078.

12. Lundberg JG, Kottelat M, Smith GR, Stiassny MLJ, Gill AC (2000) So many fishes, so little time: An overview of recent ichthyological discovery in continental waters. Ann Missouri Bot Gard 87(1): 26-62.

13. Sanches PMNA, Carvalho-Costa LF, Hatanaka T, Carrillo-Avila M, Freitas PD, et al. (2008) Contribution of conservation genetics in assessing neotropical freshwater fish biodiversity. Braz J Biol 68(4): 10391050.

14. Ardura A, Serge Planes, Eva Garcia-Vazquez (2011) Beyond biodiversity: fish metagenomes. PLoS ONE 6(8): e22592.

15. Rolls RJ, Sternberg D (2015) Can species traits predict the susceptibility of riverine fish to water resource development? an Australian case study. Environ Manage 55: 1315-1326.

16. Knouft JH, Anthony MM (2016) Climate and local abundance in freshwater fishes. R Soc Open Sci 3(3): 160093.

17. Comte L, Buisson L, Daufresne M, Grenouillet G (2013) Climate-induced changes in the distribution of freshwater fish: observed and predicted trends. Fresh Biol 58(4): 625-639.

18. Castello L, Isaac VJ, Thapa R (2015) Flood pulse effects on multispecies fishery yields in the Lower Amazon. R Soc Open Sci 2(11): 150299.

19. Isaac V I, Castello L, Brasil Santos PR, Ruffino ML (2016) Seasonal and interannual dynamics of river-floodplain multispecies fisheries in relation to flood pulses in the Lower Amazon. Fish Res 183: 352-359.

20. Zulkafli Z, Buytaert W, Manz B, Rosas CV, Willems P, et al.
(2016) Projected increases in the annual flood pulse of the Western Amazon. Environ Res Lett 11(1): 014013.

21. Alsdorf D, Bates P, Melack J, Wilson M, Dunne T (2007) Spatial and temporal complexity of the Amazon flood measured from space. Geophys Res Lett 34: L08402.

22. Hernandez PA, Graham CH, Master LL, Albert DL (2006) The effect of sample size and species characteristics on performanceof different species distribution modeling methods. Ecography 29(5): 773-785.

23. Dornelas M, Magurran AE, Buckland ST, Chao A, Chazdon RL, et al. (2013) Quantifying temporal change in biodiversity: challenges and opportunities. Proc Biol Sci 280(1750): 20121931.

24. Bálint $M$, Pfenninger $M$, Grossart $H$, Taberlet $P$, Vellend $M$, et al. (2018) Environmental DNA time series in ecology. Trends in Ecol Evol 33(12): 945-957.

25. Lapointe NWR, Corkum LD, Mandrak NE (2006) A comparison of methods for sampling fish diversity in shallow offshore waters of large rivers. N Am J Fish Manag 26(30): 503-513.

26. Gratwicke B, Speight MR (2005) The relationship between fish species richness, abundance and habitat complexity in a range of shallow tropical marine habitats. J Fish Biol 66(30): 650-667.

27. Gunzburger M (2007) Evaluation of seven aquatic sampling methods for amphibians and other aquatic fauna. Appl Herpetol 4(1): 47-63.

28. Cilleros K, Allard L, Dejean T, Etienne R, Grenouillet G, et al. (2019) Unlocking biodiversity and conservation studies in high-diversity environments using environmental DNA (eDNA): A test with Guianese freshwater fishes. Mol Ecol Res 19(41): 27-46.

29. Jerde CL, Wilson EA, Dressler TL (2019) Measuring global fish species richness with eDNA metabarcoding. Mol Ecol Res 19(1): 19-22.

30. Baird DJ, Hajibabaei M (2012) Biomonitoring 2.0: A new paradigm in ecosystem assessment made possible by next-generation DNA sequencing. Mol Ecol 21(8): 20392044.

31. Rees HC, Maddison BC, Middleditch DJ, Patmore JRM, Gough KC (2014) The detection of aquatic animal species using environmental DNA - a review of eDNA as a survey tool in ecology. J Appl Ecol 51(5): 1450-1459.

32. Ravindran S (2019) Turning discarded DNA into ecology gold. Nature 570(7762): 543-545. 
33. Miya M, Sato Y, Fukunaga T, Sado T, Poulsen JY, etal. (2015) MiFish, a set of universal PCR primers for metabarcoding environmental DNA from fishes: detection of more than 230 subtropical marine species. R Soc Open Sci 2(7): 150088.

34. Ma HJ, Kathryn S, Li-min MA, Wen-wei R, Jian-fu Z (2016) Environmental DNA and its application in protecting aquatic ecosystems. Chin J Ecol 35(2): 516-523.

35. Bohmann K, Evans A, Gilbert MTP, Carvalho GR, Creer S, et al. (2014) Environmental DNA for wildlife biology and biodiversity monitoring. Trends Ecol Evol 2(6): 358-367.

36. Pilliod DS, Goldberg CS, Arkle RS, Waits LP (2013) Estimating occupancy and abundance of stream amphibians using environmental DNA from filtered water samples. Can J Fish Aquat Sci 70 (8): 1123-1130.

37. Souza LS, Godwin JC, Renshaw MA, Larson E (2016) Environmental DNA (eDNA) detection probability is influenced by seasonal activity of organisms. PLoS ONE 11(10): e0165273.

38. Lacoursière-Roussel A, Côté G, Leclerc V, Bernatchez L (2016) Quantifying relative fish abundance with eDNA: a promising tool for fisheries management. J Appl Ecol 53(4): 1148-1157.

39. Bista I, Carvalho GR, Walsh K, Seymour M, Hajibabaei $M$, et al. (2017) Annual time-series analysis of aqueous eDNA reveals ecologically relevant dynamics of lake ecosystem biodiversity. Nat Commun 8: 14087.

40. Renshaw MA, Olds BP, Jerde CL, McVeigh MM, Lodge DM (2015) The room temperature preservation of filtered environmental DNA samples and assimilation into a phenol-chloroform-isoamyl alcohol DNA extraction. Mol Ecol Res 15(1): 168-176.

41. Eichmiller JJ, Miller LM, Sorensen PW (2016) Optimizing techniques to capture and extract environmental DNA for detection and quantification of fish. Mol Ecol Res 16(1): 56-68.

42. Mahon AR, Jerde CL, Galaska M, Bergner JL, Chadderton WL, et al. (2013) Validation of eDNA surveillance sensitivity for detection of asian carps in controlled and field experiments. PLoS ONE 8(3): e58316.

43. Jane SF, Wilcox TM, McKelvey KS, Young MK, Schwartz MK, et al. (2015) Distance, flow and PCR inhibition: eDNA dynamics in two headwater streams. Mol Ecol Res 15(1): 216-227.

44. Carraro L, Hartikainen H, Jokela J, Bertuzzo E, Rinaldo A (2018) Estimating species distribution and abundance in river networks using environmental DNA. Proc. Natl Acad Sci USA 115(46):11724-11729.

45. Pathak AK (2019) UPFBase-A freshwater fish diversity database of Uttar Pradesh, India. Indian J Anim Sci 89: 347-354.

46. Pathak AK, Nagpure NS, Kumar R, Pati R (2019) FisOmics: A portal of fish genomic resources. Genomics 111(6):1923-1928.

47. Iwasaki $\mathrm{W}$, Fukunaga $\mathrm{T}$, Isagozawa $\mathrm{R}$, Yamada $\mathrm{K}$, Maeda Y, et al. (2013) MitoFish and MitoAnnotator: A mitochondrial genome database of fish with an accurate and automatic annotation pipeline. Mol Biol Evol 30(11): 2531-2540.

48. Sato Y, Miya M, Fukunaga T, Sado T, Iwasaki W (2018) MitoFish and MiFish Pipeline: A mitochondrial genome database of fish with an analysis pipeline for environmental DNA metabarcoding. Mol Biol Evol 35(6): 1553-1555.

49. Zanzi A, Martinsohn JT (2017) FishTrace: a genetic catalogue of European fishes. Database 2017 bax075.

50. Nagpure NS, Rashid I, Pathak AK, Singh M, Pati R, et al. (2015) FMiR: A curated resource of mitochondrial DNA information for fish. PLoS ONE 10(8): e0136711.

51. Ratnasingham S, Hebert PDN (2007) BOLD: The barcode of life data system. Mol Ecol Notes 7(3): 355-364.

52. O'Leary NA, Wright MW, Brister JR, Ciufo S, Haddad D, et al. (2016) Reference sequence (RefSeq) database at NCBI: current status, taxonomic expansion, and functional annotation. Nucleic Acids Res 44: 733-745.

53. Kelly RP (2016) Making environmental DNA count. Mol Ecol Res 16: 10-12.

54. Seymour M (2019) Rapid progression and future of environmental DNA research. Commun. Biol 2(80).

55. Ruppert, Kline KM, Rahman RJ, Md Saydur (2019) Past, present, and future perspectives of environmental DNA(eDNA) metabarcoding: A systematic review in methods, monitoring, and applications of global eDNA. Glob Ecol Conserv 17(2): e00547.

56. von Winterfeldt D (2013) Bridging the gap between science and decision making. PNAS 110(3): 1405514061. 